\title{
Pengaruh Model Problem Based Learning terhadap Kemampuan Berpikir Tingkat Tinggi dan Hasil Belajar Siswa Kelas V SD
}

\author{
Risky Priliani Puspitasari ${ }^{1}$, Sutarno $^{2}$, I Wayan Dasna ${ }^{3}$ \\ ${ }^{1}$ Pendidikan Dasar-Universitas Negeri Malang \\ ${ }^{2}$ KSDP-Universitas Negeri Malang \\ ${ }^{3}$ Pendidikan Kimia-Universitas Negeri Malang
}

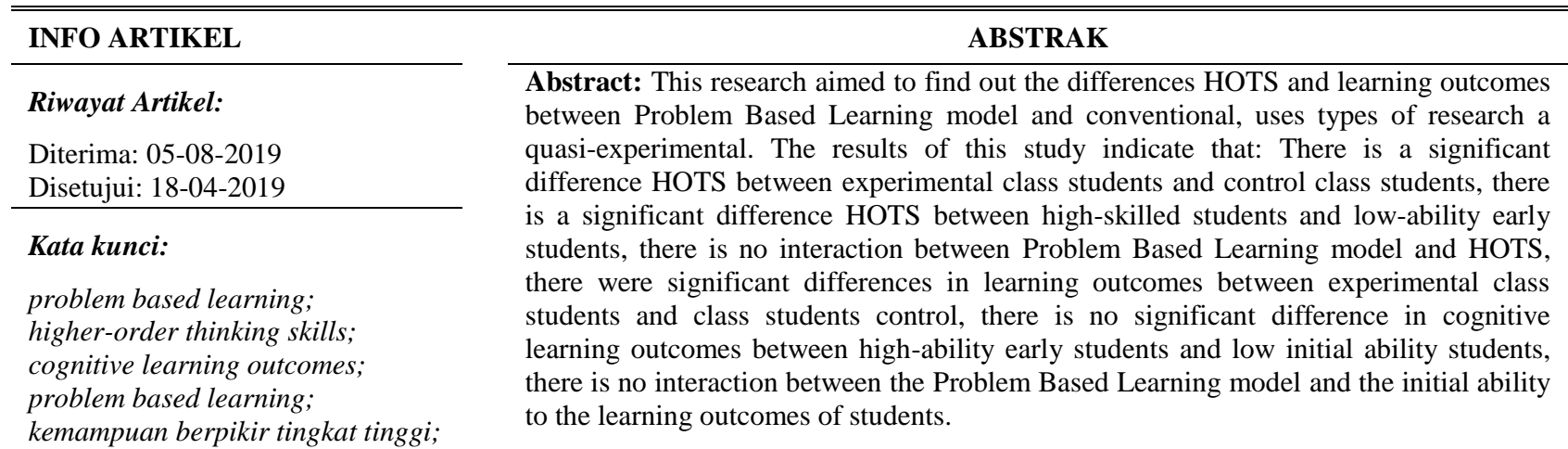

\begin{abstract}
Abstrak: Penelitian ini bertujuan untuk mengetahui perbedaan HOTS dan hasil belajar antara model Problem Based Learning dan konvensional dengan menggunakan jenis penelitian quasi experiment. Hasil penelitian menunjukkan ada perbedaan yang signifikan HOTS antara siswa kelas eksperimen dan kontrol, ada perbedaan yang signifikan HOTS antara antara siswa berkemampuan awal tinggi dan rendah, tidak ada interaksi antara model Problem Based Learning dan kemampuan awal terhadap HOTS, ada perbedaan yang signifikan hasil belajar antara siswa kelas eksperimen dan kontrol, tidak ada perbedaan yang signifikan hasil belajar antara siswa berkemampuan awal tinggi dan rendah, dan tidak ada interaksi antara model Problem Based Learning dan kemampuan awal terhadap hasil belajar.
\end{abstract}

\author{
Alamat Korespondensi: \\ Risky Priliani Puspitasari \\ Pendidikan Dasar \\ Universitas Negeri Malang \\ Jalan Semarang 5 Malang \\ E-mail: pprilianirisky@gmail.com
}

Target pembelajaran pada abad ke-21 mendorong siswa menjadi pembelajar yang aktif agar dapat mencari, menemukan, mengonstruksi, mengolah, dan menggunakan pengetahuannya sehingga akan tercipta sebuah pembelajaran bermakna. Prosesproses siswa aktif dalam abad ke-21 sudah diadaptasi dalam sistem pendidikan di Indonesia melalui kurikulum 2013 yang berlaku saat ini dengan pendekatan saintifik. Penerapan pendekatan saintifik dalam pembelajaran dilakukan dengan melibatkan prosedur $5 \mathrm{M}$, seperti mengamati, menanya, mencoba, menalar, dan mengomunikasikan. Oleh karena itu, kondisi pembelajaran diarahkan untuk mendorong siswa mencari tahu dari berbagai sumber (observasi), mampu merumuskan masalah (menanya) bukan hanya menyelesaikan masalah (Hosnan, 2016). Pelaksanan kurikulum 2013 melatih siswa agar dapat meningkatkan kemampuan berpikir tingkat tinggi atau biasa yang disebut dengan High Order Thinking Skill (HOTS). Kegiatan pembelajaran dalam kurikulum 2013 di SD berperan penting dalam pembentukan kemampuan berpikir siswa.

Pada pelaksanaan proses pembelajaran, kemampuan berpikir siswa dapat dikembangkan dengan memperkaya pengalaman yang bermakna melalui pengambilan keputusan dan pemecahan masalah yang berkaitan dengan menganalisis (analyzing), mengevaluasi (evaluating), dan mencipta (creating) (Anderson \& Krathwohl, 2015). Guru diharapkan mampu untuk melatih siswa untuk meningkatkan kemampuan berpikir tingkat tinggi dimana siswa didorong untuk menjadi siswa yang kritis. Zubaidah (2016) juga menyatakan bahwa pada abad ke-21 guru berperan sebagai pembimbing yang berupaya membantu siswa ketika menemukan kesulitan dalam proses mengonstruksi pengetahuan dan keterampilannya. Guru perlu memperkuat keingin tahuan intelektual siswa, keterampilan mengidentifikasi dan memecahkan masalah, dan kemampuan mereka untuk membangun pengetahuan baru dengan orang lain. Agar hal itu dapat terwujud maka perlu kesiapan guru secara sistematis untuk 
merancang aktivitas pembelajaran yang dapat menciptakan siswa menjadi aktif dengan mengaitkan konsep-konsep yang dipelajari oleh siswa yang menghubungkan materi pembelajaran yang diajarkan ke dalam situasi dunia nyata yang ada di lingkungan sekitar siswa. Salah satu pembelajaran yang berhubungan dengan kehidupan nyata yang ada di lingkungan sekitar siswa yaitu Ilmu Pengetahuan Alam. Ardiyanti \& Winarti (2013) menyatakan bahwa proses pembelajaran IPA tidak cukup dilaksanakan dengan menyampaikan konsep saja, akan tetapi harus memahami proses terjadinya fenomena IPA dengan melakukan penginderaan melalui kegiatan demonstrasi dan eksperimen. Pembelajaran IPA di SD diharapkan dapat dijadikan wahana bagi siswa untuk memberikan pengalaman langsung yang dapat mengembangkan kompetensi agar siswa mampu menjelajahi dan memahami alam sekitar secara ilmiah.

Hasil observasi yang ditemukan peneliti pada kegiatan pembelajaran tanggal 17-20 September di kelas V di salah satu sekolah dasar Kabupaten Trenggalek menunjukkan bahwa selama proses pembelajaran yang dilakukan, siswa kurang merespons materi yang disampaikan oleh guru. Saat guru melakukan kegiatan tanya jawab, penekanan pertanyaan yang diberikan masih pada tahap kemampuan berpikir tingkat rendah misalnya saja seperti "coba sebutkan...", "manakah yang termasuk...", siswa juga jarang bertanya mengenai hal-hal yang belum mereka pahami. Guru hanya menerima jawaban benar dari siswa dan mengabaikan jawaban yang salah. Pembelajaran belum menekankan pentingnya mendorong siswa dalam proses mencari tahu dan menemukan pengetahuan tentang apa yang mereka pelajari, masih menekankan pada transfer pengetahuan. Ketika pembelajaran IPA berlangsung siswa kurang mampu untuk menganalisis masalah yang ada di sekitarnya. Proses pembelajaran IPA banyak membutuhkan praktik, akan tetapi siswa sekedar mendengarkan penjelasan dari guru, guru lebih dominan dalam kegiatan pembelajaran. Hal tersebut menyebabkan kemampuan berpikir siswa masih kurang maksimal dan dapat memengaruhi hasil belajar. Hasil belajar siswa dalam pembelajaran, sebagian besar siswa belum memenuhi nilai standar Kriteria Ketuntasan Minimal (KKM) yang ditetapkan oleh sekolah yaitu 70. Dari 24 siswa yang mencapai KKM hanya 8 siswa.

Seiring dengan pelaksanaan kurikulum 2013 khususnya di SD yang sudah berjalan sampai saat ini diharapkan adanya perubahan pelaksanaan pembelajaran untuk mengubah pola pikir dan strategi guru dalam mengajar yang sebelumnya berpusat pada guru (teacher centered) menjadi berpusat pada siswa (student centered). Guru diharapkan lebih kreatif dan inovatif dalam penyajian materi pembelajaran. Siswa juga dibiasakan untuk melatih dan mengembangkan potensi berpikirnya. Pembelajaran IPA bukan hanya sekedar menghafal materi yang diberikan oleh guru, dibutuhkan kegiatan praktik agar siswa mengalami secara langsung, namun dalam penyampaiannya guru menjelaskan materi secara garis besar. Siswa melakukan kegiatan praktik dimaksudkan agar menemukan informasi sendiri mengenai materi pembelajaran yang sedang diajarkan namun peran guru juga dibutuhkan hanya sebagai fasilitator. Informasi yang ditemukan siswa nantinya dapat diingat lebih mudah dan bermakna sehingga memudahkan pemahaman siswa. Sesuai dengan pendapat Ipmawati (2017) dalam membelajarkan IPA pengetahuan siswa harus lebih banyak dibangun melalui pengalaman-pengalaman belajarnya yang menitikberatkan untuk melakukan percobaan dan penyajian masalah yang telah dihadirkan guru. Faktor yang memengaruhi tinggi rendahnya hasil belajar yang dapat diperoleh dari hasil observasi pada kegiatan pembelajaran di kelas $\mathrm{V}$ di atas yaitu dipengaruhi oleh kurangnya aktivitas siswa dalam proses pembelajaran. Proses pembelajaran yang belum mengikutsertakan siswa untuk aktif dan berlangsung dalam komunikasi satu arah serta belum dapat memotivasi siswa dalam belajar mengakibatkan hasil belajar siswa rendah. Guru kurang melibatkan siswa dalam proses pembelajaran yang berakibat pada kurang aktifnya siswa dalam proses pembelajaran sehingga siswa hanya terpaku pada apa yang diberikan oleh guru. Selain itu, rendahnya capaian kompetensi siswa dalam pembelajaran dikarenakan siswa kurang mampu untuk membangun konsep mereka sendiri, siswa masih kurang diberikan ruang untuk mengungkapkan kreasi berpikir mereka sehingga siswa menjadi pasif dalam pembelajaran.

Agar pembelajaran yang berlangsung dapat menarik minat siswa dan keaktifan dalam belajar, perlu diciptakan suasana pembelajaran yang menyenangkan dengan menggunakan model pembelajaran yang tepat. Dengan begitu siswa akan tertarik dalam belajar, untuk mencoba dan membuktikan sendiri, sehingga dapat memperkuat kemampuan kognitifnya dan tujuan pembelajaran dapat tercapai. Jika model pembelajaran yang digunakan kurang tepat dan bervariasi khususnya dalam pembelajaran IPA, akan berakibat kejenuhan yang nantinya akan berdampak pada kurangnya siswa dalam merespon bendabenda dan juga kejadian-kejadian di lingkungan sekitarnya, serta kurangnya kemampuan siswa dalam berpikir untuk memecahkan masalah. Penyajian materi yang mudah dimengerti siswa dan menerapkan suatu model pembelajaran dapat memberikan stimulus siswa agar dapat meningkatkan kemampuan berpikir tingkat tinggi dan memecahkan masalah. Terjadinya kemampuan berpikir tingkat tinggi akan mengarahkan pada peningkatan hasil belajar kognitif siswa (Fadhila dkk, 2013; Nugraha dkk, 2017). Salah satu cara yang digunakan agar pembelajaran dapat optimal, yaitu dengan menerapkan suatu model pembelajaran. Model Problem Based Learning merupakan salah satu model pembelajaran yang diterapkan dalam kurikulum 2013 untuk mengembangkan kemampuan berpikir siswa dan memecahkan suatu permasalahan.

Problem Based Learning membantu siswa dalam mentransfer pengetahuan faktual mereka untuk memahami masalah kontekstual yang berkaitan dengan konsep materi yang akan dipelajari, dapat meningkatkan kemampuan berpikir siswa, serta dapat mengembangkan tanggung jawab siswa menjadi pebelajar yang mandiri. Problem Based Learning diterapkan untuk merangsang berpikir tingkat tinggi dalam situasi berorientasi masalah (Anazifa, 2016; Bayrak \& Bayram, 2011; Utomo dkk, 2014). Firmansyah dkk (2015) menjelaskan bahwa Problem Based Learning memberikan kesempatan kepada siswa untuk menggali pengalaman yang autentik sehingga mendorong siswa untuk aktif belajar, mengonstruksi pengetahuan, dan mengintegrasikan ke dalam konteks belajar di sekolah dan kehidupan nyata secara ilmiah. Siswa tidak hanya sekedar mendengarkan, mencatat, dan menghafal materi yang disampaikan oleh guru, tetapi diharapkan mampu untuk berpikir, mencari, 
mengolah data, dan berkomunikasi saat kegiatan pembelajaran berlangsung. Menurut Siswanto dkk (2012) dengan menerapkan model Problem Based Learning pemahaman siswa akan bersifat long time memory (mengendap diingatan dalam waktu yang lama). Model Problem Based Learning juga melatih siswa agar dapat menganalisis dan memecahkan suatu masalah dengan tingkat kemampuan yang beragam. Siswa kelas V di SDN 3 Bendoagung mempunyai kemampuan awal yang bereda-beda. Sebelum dimulai proses pembelajaran perlu diketahui sejauh mana kemampuan awal yang dimiliki oleh siswa sebelum memperoleh pengetahuan baru. Sejalan dengan penelitian yang dilakukan oleh Praptiwi \& Handhika (2012) menegaskan bahwa kemampuan awal akan memengaruhi keberhasilan siswa dalam pembelajaran. Siswa akan lebih mudah mempelajari sesuatu apabila didasari dengan pengetahuan yang telah dimilikinya. Oleh karena itu, mempelajari suatu materi yang baru, pengalaman belajar yang dimiliki sebelumnya dapat memengaruhi terjadinya proses belajar.

Berdasarkan hasil penelitian yang dilakukan oleh: (a) Flamboyant, dkk (2018) menunjukkan bahwa terdapat pengaruh model PBL terhadap HOTS memiliki pengaruh sebesar 0,53 dengan kategori sedang, (b) Fatchiyah (2016) dari hasil T-test pada post-test dengan nilai p $0,048<0,05$. Selain itu, rata-rata post-test pada kelas eksperimen juga lebih tinggi daripada kelas kontrol yaitu 86,66 > 82,33. Hhal ini menunjukkan bahwa model Problem Based Learning memberikan pengaruh positif dan signifikan terhadap kemampuan berpikir tingkat tinggi siswa, (c) Royantoro, dkk (2018) menunjukkan bahwa hasil belajar siswa mengalami peningkatan pada kelas eksperimen yang diajarkan Problem Based Learning dari 21,33 menjadi 58,5, sedangkan pada kelas kontrol yang dibelajarkan pembelajaran konvensional dari 26,66 menjadi 51,21, dari hasil uji hipotesis menunjukkan bahwa nilai signifikansi $0,000<0,05$, dapat disimpulkan terdapat pengaruh yang signifikan HOTS siswa yang diajarkan menggunakan Problem Based Learning dengan yang diajar menggunakan model konvensional, (d) Suliyati dkk (2018) terdapat peningkatan rata-rata pre-test kelas eksperimen dan kelas kontrol masing-masing sebesar 23,72 dan 22,11 dalam kategori sangat kurang, dan untuk post-test sebesar 43,91 dan 24,14 berada di kategori cukup, hal ini menunjukkan bahwa penerapan model Problem Based Learning lebih meningkatkan hasil belajar siswa.

Dari beberapa hasil penelitian di atas menunjukkan bahwa pembelajaran menggunakan model Problem Based Learning memberikan pengaruh yang beragam, hal ini disebabkan oleh kondisi guru, kondisi siswa, dan kesesuaian materi yang diajarkan. Dalam kaitannya dengan hal ini, maka model pembelajaran yang sesuai dengan materi "siklus air" di SD kelas V yaitu model Problem Based Learning karena sesuai digunakan untuk pemecahan masalah dan menumbuhkan berpikir tingkat tinggi siswa. Pembelajaran Problem Based Learning mampu menciptakan siswa yang belajar dengan menggunakan alam sekitar sebagai media belajar untuk mencari sekaligus membangun konsep-konsep pengetahuan agar dapat mendukung pengetahuan jangka panjang siswa. Peneliti tertarik melaksanakan penelitian tentang "Pengaruh Model Problem Based Learning terhadap Kemampuan Berpikir Tingkat Tinggi dan Hasil Belajar Siswa Kelas V SDN Bendoagung 3 Kabupaten Trenggalek.”

\section{METODE}

Penelitian ini menggunakan menggunakan pendekatan kuantitatif dengan jenis penelitian quasi experiment. Desain penelitian yang digunakan yaitu Nonequivalent Control Group. Subjek penelitian yang digunakan yaitu siswa kelas V SDN Negeri 3 Bendoagung, Kabupaten Trenggalek yang terdiri dari dua kelas, kelas V A dan V B pada tahun ajaran 2018/2019 semester genap. Kelas V A ditetapkan sebagai kelas eksperimen dibelajarkan model PBL dengan jumlah 24 siswa, sedangkan kelas V B ditetapkan sebagai kelas kontrol dibelajarkan model pembelajaran konvensional 22 siswa. Variabel dalam penelitian ini yaitu variabel bebas (Model PBL dan konvensional), variabel terikat (kemampuan berpikir tingkat tinggi dan hasil belajar), dan variabel moderator (kemampuan awal).

Instrumen yang digunakan oleh peneliti yaitu pre-test dan post-test tentang kemampuan berpikir tingkat tinggi dan hasil belajar yang sebelumnya sudah divalidasi ke validator ahli. Selain itu, juga perlu dilakukan beberapa pengujian seperti validitas, reliabilitas, tingkat kesukaran butir soal, dan daya beda. Teknik analisis data dalam penelitian ini menggunakan statistik inferensial parametrik. Penghitungan analisis data ini menggunakan bantuan program SPSS 16.0 for Windows.

\section{HASIL}

Penelitian yang dilakukan pada kelas V di SDN 3 Bendoagung telah diperoleh dari data primer untuk mengukur kemampuan berpikir tingkat tinggi, hasil belajar, dan kemampuan awal siswa dalam bentuk soal multiple choice. Jumlah siswa dalam penelitian ini adalah 46 yang terbagi dalam dua kelas, dengan rincian 24 siswa kelas eksperimen pada siswa kelas V A dan 22 siswa kelas kontrol pada siswa kelas V B. Pada kelas eksperimen diterapkan model Problem Based Learning dan kelas kontrol diterapkan model konvensional. Data kemampuan awal siswa diperoleh dari nilai hasil pre-test yang dilaksanakan di kelas eksperimen dan kontrol sebelum proses pembelajaran pada materi "siklus air". Pelaksanaan pre-test bertujuan untuk mengetahui apakah kemampuan awal yang dimiliki oleh siswa di kedua kelas tersebut sama. Data kemampuan awal siswa kelas eksperimen dan kontrol dapat dilihat pada tabel 1. 
Tabel 1. Data Kemampuan Awal Siswa

\begin{tabular}{|c|c|c|c|c|c|}
\hline Kelas & Jumlah Siswa & Nilai Maksimal & Nilai Minimal & Rata-rata & Stdev \\
\hline Eksperimen (Model Pembelajaran Problem Based Learning) & 24 & 68 & 41 & 51,9 & 8,1 \\
\hline Kontrol (Model Pembelajaran Konvensional & 22 & 68 & 41 & 54,1 & 7,9 \\
\hline
\end{tabular}

Tabel 1 menunjukkan bahwa nilai rata-rata kemampuan awal siswa pada kelas eksperimen yaitu 51,9 sedangkan pada kelas kontrol yaitu 54,1. Nilai maksimum dan nilai minimum pada kedua kelas eksperimen maupun kontrol memiliki nilai yang sama. Hal ini menunjukkan bahwa nilai rata-rata kemampuan awal pada kedua kelas masih kurang. Nilai standar Kriteria Ketuntasan Minimal (KKM) pada muatan IPA yang ditetapkan SDN 3 Bendoagung yaitu 70. Kemampuan awal siswa dari kelas eksperimen dan kelas kontrol dikelompokkan menjadi dua kelompok yakni kelompok siswa dengan kemampuan awal tinggi dan kelompok siswa dengan kemampuan awal yang rendah. Pengelompokkan ini diterapkan sebelum kelas mengalami perlakuan model pembelajaran.

Data kemampuan berpikir tingkat tinggi siswa diperoleh dari nilai hasil post-test yang dilaksanakan di kelas eksperimen dan kelas kontrol setelah siswa mendapatkan materi "siklus air". Jumlah soal tes untuk mengukur kemampuan berpikir tingkat tinggi terdiri dari 10 butir soal. Data kemampuan berpikir tingkat tinggi siswa dapat dilihat pada tabel 2.

Tabel 2. Data Kemampuan Berpikir Tingkat Tinggi Siswa

\begin{tabular}{lccccc}
\hline \multicolumn{1}{c}{ Kelas } & Jumlah Siswa & Nilai Maksimal & Nilai Minimal & Rata-rata & Stdev \\
\hline Eksperimen & 24 & 100 & 60 & 80,8 & 12,8 \\
Kontrol & 22 & 100 & 50 & 72,7 & 14,9 \\
\hline
\end{tabular}

Tabel 2 menunjukkan bahwa nilai rata-rata kemampuan berpikir tingkat tinggi siswa pada kelas eksperimen yaitu 80,8 sedangkan pada kelas kontrol yaitu 72,7. Nilai maksimum pada kedua kelas eksperimen maupun kontrol memiliki nilai yang sama, sedangkan untuk nilai minimum kelas eksperimen yaitu 60 dan kelas kontrol 50.

Data hasil belajar siswa diperoleh dari nilai hasil post-test yang dilaksanakan di kelas eksperimen dan kelas kontrol setelah siswa mendapatkan materi "siklus air". Jumlah soal tes untuk mengukur hasil belajar siswa terdiri dari 12 butir soal. Data hasil belajar siswa dapat dilihat pada tabel 3.

Tabel 3. Data Hasil Belajar Siswa

\begin{tabular}{lccccc}
\hline Kelas & Jumlah Siswa & Nilai Maksimal & Nilai Minimal & Rata-rata & Stdev \\
\hline Eksperimen & 24 & 100 & 67 & 85,1 & 10,2 \\
Kontrol & 22 & 100 & 58 & 76,5 & 11,6 \\
\hline
\end{tabular}

Tabel 3 menunjukkan bahwa nilai rata-rata hasil belajar siswa pada kelas eksperimen yaitu 85,1 sedangkan pada kelas kontrol yaitu 76,5. Nilai maksimum pada kedua kelas eksperimen maupun kontrol memiliki nilai yang sama, sedangkan untuk nilai minimum kelas eksperimen yaitu 67 dan kelas kontrol 58.

Uji hipotesis pada penelitian ini melalui bantuan program SPSS 16.0 for Windows menggunakan uji MANOVA (Multivariate Analysis of Variance). Adapun hasil uji hipotesis variabel kemampuan berpikir tingkat tinggi dan hasil belajar pada kelas eksperimen dan kontrol dapat dilihat pada tabel 4.

Tabel 4. Hasil Uji Hipotesis Variabel Kemampuan Berpikir Tingkat Tinggi dan Hasil Belajar Siswa

Tests of Between-Subjects Effects

\begin{tabular}{|ll|l|l|l|l|l|}
\hline Source & Dependent Variable & Type III Sum of Squares & df & Mean Square & \multicolumn{1}{|c|}{ F } & Sig. \\
\hline Corrected Model & HOTS & $2609.127^{\mathrm{a}}$ & 3 & 869.709 & 5.564 & .003 \\
& Hasil Belajar & $1303.570^{\mathrm{b}}$ & 3 & 434.523 & 3.844 & .016 \\
\hline Intercept & HOTS & 248614.238 & 1 & 248614.238 & $1.591 \mathrm{E} 3$ & .000 \\
& Hasil Belajar & 280694.359 & 1 & 280694.359 & $2.483 \mathrm{E} 3$ & .000 \\
\hline Kelas & HOTS & 679.035 & 1 & 679.035 & 4.344 & .043 \\
& Hasil Belajar & 796.710 & 1 & 796.710 & 7.048 & .011 \\
\hline Kemampuan_Awal & HOTS & 1850.375 & 1 & 1850.375 & 11.838 & .001 \\
& Hasil Belajar & 453.761 & 1 & 453.761 & 4.014 & .052 \\
\hline Kelas* Kemampuan_Awal & HOTS & 11.122 & 1 & 11.122 & .071 & .791 \\
& Hasil Belajar & 6.953 & 1 & 6.953 & .062 & .805 \\
\hline
\end{tabular}


Tabel 4. Hasil Uji Hipotesis Variabel Kemampuan Berpikir Tingkat Tinggi dan Hasil Belajar Siswa (Lanjutan)

\begin{tabular}{|ll|l|l|l|l|l|}
\hline Error & HOTS & $\begin{array}{l}6564.786 \\
4747.409\end{array}$ & 42 & 156.304 & & \\
& Hasil Belajar & 42 & 113.034 & & \\
\hline Total & HOTS & 281600.000 & 46 & & & \\
& Hasil Belajar & 307695.000 & 46 & & & \\
\hline Corrected Total & HOTS & 9173.913 & 45 & & & \\
& Hasil Belajar & 6050.978 & 45 & & & \\
\hline
\end{tabular}

Hasil uji hipotesis variabel kemampuan berpikir tingkat tinggi dan hasil belajar yang tertera pada tabel 4 dapat digunakan untuk menjawab hipotesis yang telah diajukan. Hipotesis pertama diperoleh dengan nilai signifikansi $0,043<0,05$, sehingga $\mathrm{H}_{0}$ ditolak dan $\mathrm{H}_{1}$ diterima. Jadi, dapat disimpulkan bahwa ada perbedaan yang signifikan kemampuan berpikir tingkat tinggi antara siswa kelas eksperimen dan siswa kelas kontrol.

Hipotesis kedua diperoleh dengan nilai signifkansi $0,001<0,05$, sehingga $\mathrm{H}_{0}$ ditolak dan $\mathrm{H}_{1}$ diterima. Dapat disimpulkan bahwa ada perbedaan yang signifikan kemampuan berpikir tingkat tinggi antara siswa berkemampuan awal tinggi dengan siswa berkemampuan awal rendah.

Hipotesis ketiga diperoleh dengan nilai signifikansi $0,791>0,05$, sehingga $\mathrm{H}_{0}$ diterima dan $\mathrm{H}_{1}$ ditolak. Jadi, dapat disimpulkan bahwa tidak ada interaksi antara model Problem Based Learning dan kemampuan awal terhadap kemampuan berpikir tingkat tinggi siswa.

Hipotesis keempat diperoleh dengan nilai signifikansi $0,011<0,05$, sehingga $\mathrm{H}_{0}$ ditolak dan $\mathrm{H}_{1}$ diterima. Dapat disimpulkan bahwa ada perbedaan yang signifikan hasil belajar kognitif siswa antara siswa kelas eksperimen dan siswa kelas kontrol.

Hipotesis kelima diperoleh dengan nilai signifikansi $0,052>0,05$, sehingga $\mathrm{H}_{0}$ diterima dan $\mathrm{H}_{1}$ ditolak. Dapat disimpulkan bahwa tidak ada perbedaan yang signifikan hasil belajar kognitif antara siswa berkemampuan awal tinggi dengan siswa berkemampuan awal rendah.

Hipotesis keenam diperoleh dengan nilai signifikansi $0,805>0,05$, sehingga $\mathrm{H}_{0}$ diterima dan $\mathrm{H}_{1}$ ditolak. Dapat disimpulkan bahwa tidak ada interaksi antara model Problem Based Learning dan kemampuan awal terhadap hasil belajar kognitif siswa.

\section{PEMBAHASAN}

\section{Pengaruh Kemampuan Berpikir Tingkat Tinggi antara Siswa Kelas Eksperimen dan Siswa Kelas Kontrol}

Berdasarkan hasil analisis data menunjukkan bahwa kemampuan berpikir tingkat tinggi siswa kelas eksperimen lebih baik daripada kelas kontrol. Hal ini tidak terlepas dari adanya perbedaan karakteristik tahapan model Problem Based Learning dengan model pembelajaran konvensional. Pada pembelajaran materi "siklus air" di kelas eksperimen, ketuntasan belajar siswa lebih banyak dibandingkan di kelas kontrol. Tahapan Problem Based Learning dalam pembelajaran dimulai dari orientasi masalah terhadap siswa, gambar diberikan pertama kali kepada siswa yang memungkinkan siswa untuk menciptakan pembelajaran yang berpusat pada siswa, sehingga siswa dapat memiliki kemampuan berpikir dan pemecahan masalah pada gambar yang disajikan. Berdasarkan jawaban siswa pada LKS, siswa kelas eksperimen dengan dibelajarkan model Problem Based Learning sudah mendekati jawaban benar dibandingkan siswa kelas kontrol dengan model konvensional. Tahap kedua yaitu mengorganisasi siswa untuk belajar, siswa diminta untuk membentuk kelompok dan menuliskan tugas-tugas setiap anggota kelompok. Setelah itu, tahap membimbing penyelidikan individu dan kelompok, tahap ini beberapa siswa menuliskan secara lengkap alat dan bahan serta langkah pembuatan percobaan pada LKS namun juga masih ada siswa yang hanya menuliskan beberapa bagian tentang alat dan bahan serta langkah pembuatan percobaan pada LKS. Siswa terlihat lebih aktif dalam kegiatan diskusi melakukan percobaan sederhana pada kelas kontrol maupun eksperimen. Hal ini dikarenakan siswa sudah memiliki konsep yang berasal dari tahap sebelumnya. Meskipun kedua kelas sama-sama menunjukkan keaktifan dalam berdiskusi kelompok, tetapi siswa pada kelas eksperimen lebih cepat menjawab pertanyaan. Tahap selanjutnya yaitu mengembangkan dan menyajikan hasil karya, di tahap ini siswa diminta untuk menjelaskan konsep yang diperoleh pada tahap sebelumnya, yakni siswa diminta untuk melakukan presentasi.

Kegiatan selanjutnya yaitu tahap menganalisis dan mengevaluasi proses pemecahan masalah, siswa diberikan kesempatan untuk menanyakan konsep yang masih belum jelas dan belum mereka pahami selama proses pemelajaran. Guru memberikan kesempatan kepada siswa untuk menjawab pertanyaan yang diberikan oleh temannya yang lain. Hal ini dimaksudkan untuk melihat konsep yang dimiliki siswa setelah diterapkannya model pembelajaran yang menggunakan tahapan Problem Based Learning. Selain itu, juga dapat melatih kemampuan siswa untuk mengemukakan pendapat serta menyampaikan konsep yang mereka miliki untuk membantu kesulitan yang dialami siswa lain. Meningkatkan kemampuan berpikir tingkat 
tinggi dilakukan dengan cara menganalisis, mengevaluasi, dan mencipta berdasarkan Taksonomi Bloom yang telah direvisi. Selain itu, peningkatan kemampuan berpikir tingkat tinggi dapat dilakukan dengan menerapkan model pembelajaran aktif yang berpusat pada siswa dan didasarkan pada konstruktivisme (Limbach \& Waugh, 2010). Model pembelajaran yang didasarkan pada konstruktivisme dan pembelajaran aktif yang dapat mengakomodasi siswa untuk dapat mengembangkan kemampuan menganalisis, mengevaluasi dan mencipta yaitu model Problem Based Learning (Afandi, 2016; Magsino, 2014; Sastrawati dkk, 2011; Wulandari \& Surjono, 2013). Model Problem Based Learning dapat memaksimalkan kemampuan siswa untuk mengonstruksi definisi konsep melalui gagasan, ide, pengalaman, dan fakta yang diaplikasikan dalam pencarian suatu solusi untuk mengatasi permasalahan yang dihadapi (Wikanso, 2013).

\section{Pengaruh Kemampuan Berpikir Tingkat Tinggi antara Siswa Berkemampuan Awal Tinggi dan Siswa Berkemampuan Awal Rendah}

Hasil analisis data yang telah dilakukan ada perbedaan yang signifikan kemampuan berpikir tingkat tinggi antara siswa berkemampuan awal tinggi dan siswa berkemampuan awal rendah. Kemampuan berpikir tingkat tinggi dalam penelitian ini siswa yang berkemampuan awal tinggi juga akan memiliki kemampuan berpikir yang tinggi, begitupun sebaliknya. Setiap proses pembelajaran mempunyai titik tolaknya sendiri atau berpangkal pada kemampuan awal siswa tertentu untuk dikembangkan menjadi kemampuan baru, setiap apa yang menjadi tujuan dalam proses pembelajaran. Kemampuan awal juga menggambarkan kesiapan siswa dalam menerima materi pelajaran baru yang akan diberikan oleh guru. Siswa yang mempunyai kemampuan awal yang rendah akan lebih sulit untuk menerima dan memahami pembelajaran. Pembelajaran akan lebih mudah diterima atau dimengerti oleh siswa yang mempunyai kemampuan awal yang tinggi. Siswa menggunakan kemampuan awalnya untuk menyeleksi informasi, menambah informasi yang dimiliki dan membangun mental berpikir. Kemampuan awal disimpan dalam ingatan jangka panjang sehingga suatu saat jika diperlukan dapat digunakan kembali. Siswa dengan kemampuan awal yang lebih tinggi akan lebih mudah untuk memahami suatu konsep. Konstruksi konsep yang akan dipelajari oleh suatu individu sangat dipengaruhi oleh kemampuan awalnya (Hendryawan dkk, 2017; Kozma, 2003).

\section{Interaksi antara Model Problem Based Learning dan Kemampuan Awal terhadap Kemampuan Berpikir Tingkat Tinggi Siswa}

Hasil analisis data disimpulkan bahwa tidak ada interaksi antara Model Problem Based Learning dan kemampuan awal terhadap kemampuan berpikir tingkat tinggi siswa. Kemampuan awal siswa di kelas bisa bervariasi tingkatannya antara seorang siswa dan siswa lain. Inilah yang utama harus diperhatikan oleh perancang pengajaran (Uno, 2008). Pengaruh antara model pembelajaran dan kemampuan awal siswa (rendah, tinggi) kemampuan terhadap kemampuan berpikir tingkat tinggi siswa disebut dengan interaksi antara model pembelajaran dan kemampuan awal siswa. Hal ini diduga disebabkan oleh kuatnya masing-masing pengaruh variabel bebas terhadap variabel terikat sehingga faktor ini dapat melemahkan interaksi dari setiap variabel. Dapat dikatakan tidak adanya interaksi menunjukkan jika variabel bebas (model Problem Based Learning) dan variabel bebas lainnya/moderator (kemampuan awal) lebih membawa pengaruh terpisah yang signifikan terhadap variabel terikat (kemampuan berpikir tingkat tinggi) atau masing-masing Variabel bebas mempunyai pengaruh utama yang signifikan. Hal ini sejalan dengan pendapat (Hair dkk, 1995) bahwa tidak terjadinya interaksi disebabkan jika dua variabel membawa pengaruh secara terpisah yang sangat kuat (signifikan) terhadap variabel terikat. Model Problem Based Learning lebih memengaruhi kemampuan berpikir tingkat tinggi yaitu terlihat pada kelompok tinggi-rendah eksperimen dan kontrol.

\section{Pengaruh Hasil Belajar Kognitif antara Siswa Kelas Eksperimen dan Siswa Kelas Kontrol}

Berdasarkan hasil analisis data yang telah dilakukan menunjukkan bahwa hasil belajar kognitif siswa kelas eksperimen lebih baik daripada kelas kontrol. Hal ini tidak terlepas dari adanya perbedaan karakteristik tahapan model Problem Based Learning dengan model pembelajaran konvensional. Pelaksanaan model Problem Based Learning memberikan pengaruh positif terhadap hasil belajar. Hasil belajar kognitif siswa dapat dipengaruhi oleh banyak faktor termasuk didalamnya yaitu penggunaan model pembelajaran. Problem Based Learning yang diterapkan ini memiliki beberapa tahapan pelaksanaan yang terdiri dari lima tahapan.

Tahap pertama orientasi masalah. Pada tahap ini guru menjelaskan tujuan pembelajaran secara umum serta memberikan motivasi bagi siswa mengenai kegiatan pembelajaran. Tahap orientasi masalah dimanfaatkan guru untuk membuka pemikiran siswa mengenai pembelajaran yang dilaksanakan. Pembelajaran yang akan dilaksanakan yaitu pembelajaran yang berorientasi pada masalah kontekstual atau masalah yang ada di sekitar siswa. Siswa diberikan informasi mengenai keterkaitan anatara pembelajaran kontekstual dengan materi dan tujuan pembelajaran yang akan ditempuh.

Tahap kedua pengorganisasian siswa dalam belajar. Pembelajaran dengan model Problem Based Learning pada tahap ini guru menjelaskan tugas-tugas yang harus dilakukan oleh siswa. Pada saat penelitian di tahap kedua ini peneliti mulai menjelaskan mengenai sistematika proses pembelajaran dengan menggunakan model pembelajaran Problem Based Learning kepada siswa. Hal yang dilakukan yaitu menjelaskan tentang masalah lingkungan yang kontekstual kepada siswa terutama masalah limbah tahu. Pada tahap ini guru menginformasikan mengenai langkah pembuatan tugas kepada siswa yang akan dibuat dalam bentuk laporan atau karya termasuk pembagian kelompok siswa. 
Tahap ketiga membimbing penyelidikan secara individu dan kelompok. Pada tahap ini guru memotivasi siswa dalam proses pengumpulan informasi yang berhubungan dengan maslaah yang dipilih siswa. Pada tahap ini siswa bisa menceritakan kendala atau masalah yang dihadapi saat melakukan kegiatan penyelidikan. Guru pada tahap ini memberikan bantuan kepada siswa dalam hal meluruskan pemahaman siswa mengenai tugas yang mereka kerjakan. Guru membantu siswa untuk menjelaskan tentang cara membuat hasil karya secara sistematis dan berurutan sesuai dengan aturan yang telah dibuat oleh peneliti.

Pada tahap keempat mengembangkan dan menyajikan hasil karya. Model Problem Based Learning mengarahkan siswa untuk menghasilkan sebuah produk berupa laporan diskusi kelompok dan hasil karya pembuatan penjernihan air sederhana yang nantinya akan dipresentasikan di depan kelas. Pada tahap ini akan terjadi proses tanya jawab dan diskusi baik antar siswa maupun siswa dengan guru. Masing-masing kelompok mempertanggungjawabkan tugas mereka ke depan kelas. Kelompok pada kelas eksperimen ini dibagi dalam enam kelompok.

Tahap kelima menganalisis dan evaluasi proses pemecahan masalah. Pada tahap ini siswa dan guru melakukan refleksi dan evaluasi terhadap hasil diskusi dan presentasi. Pada penelitian ini, tahap ini menjadi tahap terakhir dalam penerapan model Problem Based Learning. Hal yang dilakukan yaitu guru dan siswa secara bersama-sama menyimpulkan hasil diskusi dari setiap kelompok dan menentukan solusi yang tepat dan logis terhadap permasalahan yang ditemui. Hasil penelitian yang diperoleh dalam penelitian ini sesuai dengan penelitian Wulandari \& Surjono (2013) bahwa terdapat perbedaan hasil belajar yang signifikan antara siswa yang diajar model Problem Based Learning dengan siswa yang diajarkan menggunakan metode demonstrasi.

\section{Pengaruh Hasil Belajar Kognitif antara Siswa Berkemampuan Awal Tinggi dan Siswa Berkemampuan Awal Rendah}

Hasil analisis data yang telah dilakukan tidak ada perbedaan yang signifikan hasil belajar kognitif antara siswa berkemampuan awal tinggi dan siswa berkemampuan awal rendah. Setiap individu mempunyai kemampuan awal yang berbeda. Kemampuan awal didefinisikan sebagai pengetahuan atau kemampuan yang dimiliki siswa sebelum menempuh perjalanan berikutnya. Hal ini kurang sesuai dengan pendapat dari Uno (2006) bahwa siswa membawa pengalaman dan pengetahuan sebelumnya yang berguna untuk pemahaman konsep baru. Oleh karena itu, seharusnya kemampuan awal berpengaruh pada hasil belajar siswa. Penelitian ini menunjukkan hasil berbeda dengan pendapat tersebut, perbedaan tingkat kemampuan awal siswa ternyata tidak memberikan pengaruh yang signifikan terhadap hasil belajar kognitif siswa.

\section{Interaksi antara Model Problem Based Learning dan Kemampuan Awal terhadap Hasil Belajar Kognitif Siswa}

Hasil analisis data yang telah dilakukan tidak ada interaksi antara Model Problem Based Learning dan kemampuan awal terhadap hasil belajar kogntif siswa. Tidak ada interaksi yang signifikan antara model Problem Based Learning dan kemampuan awal terhadap hasil belajar, karena dengan melihat rata-rata hasil belajar yang diperoleh dari kedua model pembelajaran dapat dikatakan model Problem Based Learning dan konvensional sama-sama dapat meningkatkan hasil belajar kognitif siswa. Hasil penelitian ini sejalan dengan penelitian Setioko (2015) yang menyatakan bahwa hasil belajar kognitif siswa tidak dipengaruhi oleh model pembelajaran dan kemampuan awal siswa pada materi termokimia. Faktor yang menjadi penyebab tidak adanya interaksi antara Problem Based Learning dan kemampuan awal terhadap hasil belajar kognitif siswa dikarenakan dengan menggunakan model apapun siswa yang memiliki kemampuan awal tinggi memiliki hasil belajar yang tinggi begitu pula sebaliknya. Kemampuan awal masing-masing individu berbeda-beda, mereka harus mampu untuk mengeksplorasi kemampuan awal agar dapat meningkat. Jika ada siswa yang memiliki nilai kemampuan awal tinggi, tetapi tidak dapat mengeksplorasi akan berakibat pada penurunan hasil belajar siswa, dapat disimpulkan bahwa model Problem Based Learning dengan kemampuan awal tidak memberikan pengaruh yang signifikan terhadap hasil belajar siswa karena kemampuan awal sudah ada dalam individu masing-masing yang hanya dapat dikembangkan dengan keinginan diri.

\section{SIMPULAN}

Berdasarkan hasil penelitian yang diperoleh dari penelitian ini sebagai berikut: (1) Ada perbedaan yang signifikan kemampuan berpikir tingkat tinggi antara siswa kelas eksperimen dan siswa kelas kontrol, (2) ada perbedaan yang signifikan kemampuan berpikir tingkat tinggi antara siswa berkemampuan awal tinggi dan siswa berkemampuan awal rendah, (3) tidak ada interaksi antara model Problem Based Learning dan kemampuan awal terhadap kemampuan berpikir tingkat tinggi siswa, (4) ada perbedaan yang signifikan hasil belajar kognitif antara siswa kelas eksperimen dan siswa kelas kontrol, (5) tidak ada perbedaan yang signifikan hasil belajar kogntif antara siswa berkemampuan awal tinggi dan siswa berkemampuan awal rendah, dan (6) tidak ada interaksi antara model Problem Based Learning dan kemampuan awal terhadap hasil belajar kognitif siswa.

Mengacu pada hasil penelitian yang diperoleh, maka saran dalam penelitian ini yaitu model Problem Based Learning untuk meningkatkan kemampuan berpikir tingkat tinggi dan hasil belajar siswa. Kemampuan awal merupakan faktor internal siswa yang mempunyai pengaruh pada kemampuan berpikir tingkat tinggi dan hasil belajar siswa. Guru hendaknya dapat membangkitkan atau meningkatkan kemampuan awal siswa agar kemampuan berpikir tingkat tinggi dan hasil belajar siswa dapat meningkat. 


\section{DAFTAR RUJUKAN}

Afandi. (2011). Pembelajaran Biologi Menggunakan Pendekatan Metakogntif melalui Model Reciprocal Teaching dan Problem Based Learning ditinjau dari Kemandirian Belajar dan Kemampuan Berpikir Kritis Mahasiswa. Jurnal Pendidikan Matematika, 2(2), 1-7.

Anazifa, R. D. (2016). The Effect of Problem-Based Learning on Critical Thinking and Student Achievement in The 1 Bantul Senior High School. International Conference on Educational Research and Innovation, 6(2), 190-193.

Anderson, L.W., \& Krathwohl, D. R. (Eds). (2015). Kerangka Landasan untuk Pembelajaran, Pengajaran, dan Asesmen: Revisi Taksonomi Pendidikan Bloom. Terjemahan: Agung Prihantoro. Yogyakarta: Pustaka Belajar. (Buku asli diterbitkan tahun 2001).

Ardiyanti, F. W. (2013). Pengaruh Model Pembelajaran Berbasis Fenomena Meningkatkan Keterampilan Berpikir Kritis Siswa Sekolah Dasar. Kaunia: Integration and Interconnection Islam and Science, 9(2), 27-33.

Bayrak, B. K., \& Bayram, H. (2011). Effects of Problem-Based Learning in a Web Environment on Conceptual Understanding: The Subject of Acids and Bases. International Online Journal of Educational Sciences, 3(3), 831—848,

Fadhila, C., Aloysius, D. C., Balqis. (2013). Pengaruh Model Problem Based Learning terhadap Kemampuan Berpikir Tingkat Tinggi dan Hasil Belajar Siswa Kelas X SMA \& Malang. Jurnal Pendidikan Hayati Universitas Negeri Malang, 2(1), $1-10$.

Fatchiyah. (2016). Pengaruh PBL terhadap Kemampuan Berpikir Tingkat Tinggi Siswa Kelas V SD Se-Gugus 01 Kretek. Jurnal Pendidikan Guru Sekolah Dasar, 18(5), 1737-1745

Flamboyant, U. F., Murdani, E., \& Soeharto. (2018). Pengaruh Model Prolem Based Learning terhadap Higher Order Thinking Skills Peserta Didik SMA Negeri di Kota Singkawang Materi Hukum Archimedes. Jurnal Pendidikan IPA STKIP Singkawang, 1(2), 51-59

Firmansyah, A., Kosim., \& Ayub, S. (2015). Pengaruh Model Pembelajaran Berbasis Masalah dengan Metode Eksperimen pada Materi Cahaya terhadap Hasil Belajar Fisika Siswa Kelas VIII SMPN 2 Gunungsari Tahun Ajaran 2014/2015. Jurnal Pendidikan Fisika dan Teknologi, 1(3), 154-159.

Hair, J. F., Anderson, R. E., Tatham, R. L., \& Balck, W. C. (1995). Multivariate Data Analysis with Reading;Fourth Edition. New Jersey:Prenctice-Hall,Inc

Hendryawan, S., Yusuf, Y., Wachyar, T. Y., Siregar, I., \& Dwiyanti, W. (2017). Analisis Kemampuan Berpikir Kritis Matematis Siswa SMP Tingkat Rendah pada Pembelajaran Berbasis Masalah dengan Green's Motivational Strategies. Aksioma: Jurnal Matematika dan Pendidikan Matematika, 8(2), 50-58.

Hosnan, M. (2016). Pendekatan Saintifik dan Kontekstual dalam Pembelajaran Abad 21. Bogor: Ghalia Indonesia.

Ipmawati, N. (2017). Penerapan PBL dalam Mata Pelajaran IPA untuk Meningkatkan Hasil Belajar Siswa. Seminar Nasional Biologi, IPA dan Pembelajarannya I, Universitas Muhammadiyah Jember, 262-276.

Kozma, R. 2003. The Material Features of Multiple Representations and Their Cognitive and Social Affordances for Science Understanding. Journal Science Direct, 13(2), 205-226.

Limbach, B., \& Waugh, W. 2010. Developing Higher Level Thinking. Journal of Chemical Education, 3, 1-9.

Magsino, R. M. 2014. Enhancing Higher Order Thinking Skills in a Marine Biology Class through Problem-Based Learning, Asia Pacific Journal of Multidiciplinary Research, 2(5), 1-6.

Nugraha, A. J., Suyitno, H., \& Susilaningsih, E. (2017). Analisis Kemampuan Berpikir Kritis Ditinjau dari Keterampilan Proses Sains dan Motivasi Belajar melalui Model PBL. Journal of Primary Education, 6(1), 35-43.

Praptiwi., \& Handika. (2012). Efektivitas Metode Kooperatif Tipe GI dan STAD ditinjau dari Kemampuan Awal. Jurnal Penelitian Pembelajara Fisika, 3(1), 41-50.

Royantoro, F., Mujasam., Yusuf, I., \& Widyaningsih, S.W. (2018). Pengaruh Model Problem Based Learning terhadap Higher Order Thinking Skill Peserta Didik. Jurnal Ilmiah Pendidikan Fisika, 6(3), 371-382.

Sastrawati, E., Rusdi, M., \& Syamsurizal. (2011). Problem Based Learning, Strategi Metakognisi, dan Keterampilan Berpikir Tingkat Tinggi Siswa. Jurnal Tekno-Pedagogi, 1(2), 1-14.

Setioko, B. (2015). Pengaruh Penerapan Pembelajaran Problem Based Learning (PBL) dan Kemampuan Awal terhadap Hasil Belajar Kognitif, Kemampuan Berpikir Tingkat Tinggi dan Pengembangan Keterampilan Proses Sains Siswa pada Materi Termokimia. Tesis tidak diterbitkan. Universitas Negeri Malang, Malang.

Siswanto., Maridi., \& Marjono. (2012). Pengaruh Model Problem Based Learning (PBL) terhadap Kemampuan Memecahkan Masalah dan Hasil Belajar Kognitif Biologi Siswa Kelas VII SMP Negeri 14 Surakarta Tahun Pelajaran 2011/2012. Jurnal Pendidikan Biologi, 4(2), 53-59.

Suliyati, S., Mujasam, M., Yusuf, I., \& Widyaningsih, S. W. (2018). Penerapan Model PBL Menggunakan Alat Peraga Sederhana terhadap Hasil Belajar Siswa. Curricula: Journal of Teaching and Learning, 3(1), 11-22.

Uno, H. B. (2006). Perencanaan Pembelajaran. Jakarta: Bumi Aksara.

Utomo, T., Wahyuni, D., \& Hariyadi, S. (2014). Pengaruh Model Pembelajaran Berbasis Masalah (Problem Based Learning) terhadap Pemahaman Konsep dan Kemampuan Berpikir Kreatif Siswa (Siswa Kelas VIII Semester Gasal SMPN 1 Sumbermalang Kabupaten Situbondo Tahun Ajaran 2012/2013). Jurnal Edukasi, 1(1), 5-9. 
Wikanso. (2013). Peningkatan Motivasi Belajar, Kemampuan Berpikir Kritis, dan Prestasi Belajar melalui Strategi Pembelajaran Berbasis Masalah dengan Metode Inquiry pada Mahasiswa Semester III Program Studi Bahasa Indonesia STKIP PGRI Ngawi. Jurnal Ilmiah STKIP PGRI Ngawi, 12(2), 39-49.

Wulandari, B., \& Surjono, H. D. (2013). Pengaruh Problem-Based Learning terhadap Hasil Belajar ditinjau dari Motivasi Belajar PLC di SMK. Jurnal Pendidikan Vokasi, 3(2), 178-191

Zubaidah, S. (2016). Keterampilan Abad Ke-21: Keterampilan yang diajarkan melalui Pembelajaran. Conferences Paper. Jurusan Biologi Universitas Negeri Malang , 1-17. 